DOI https://doi.org/10.18551/rjoas.2021-01.22

\title{
BUSINESS DEVELOPMENT STRATEGY FOR SME - SNACK PREFERENCES OF MILLENNIAL GENERATION: A CASE STUDY OF A FISH-BASED CRACKER PRODUCER IN INDONESIA
}

\author{
Wijayanti Silvana Kardinar*, Fahleti Widya Hana \\ Tenggarong School of Economics, East Kalimantan, Indonesia \\ *E-mail: silvana.dinar@gmail.com
}

\begin{abstract}
The development of technology and internet has made business competition even more fierce and intensive. Consumers increasingly have bargaining power with sellers as a result of the flow of information that is increasingly accessible regarding the price, quality and specifications of a product. On the other hand, currently millennial generation is the group of consumers with the largest population and is predicted to have the purchasing power to surpass the baby boomers generation. This condition is a promising opportunity as well as a challenge for business development. This study aims to identify and formulate a business development strategy for "Wanita Pesisir", a SME that produces milkfish amplang cracker located in Saliki Village, Muara Badak District, East Kalimantan Province. Using sequential mixed method through distributing questionnaires to 68 millennial consumers online to describe their preferences and snack buying behavior, then follwoed by a focus group discussion (FGD) with the group members of "Wanita Pesisir" to identify the strengths and weaknesses of the organization from the internal side and the opportunities and threats that exist from the external side. Results of this research found that millennial customers are more health conscious and demanding for healthy and tasty snacks. Wanita Pesisir currently is in a good position so it should use aggressive strategy to expand its business.
\end{abstract}

\section{KEY WORDS}

Cracker, millennial generation, consumer behaviour, development, business strategy.

Government and academics agree that SMEs play important roles in the economy such as creating more jobs, contributing to a country's GDP, helping in maintaining economy stability, etc. So that, recently Indonesia government put more efforts to push and help SMEs to grow bigger and stronger (Cakti, 2020).

If tourists visit East Kalimantan Province, one of the mandatory souvenirs to bring home is amlpang crackers. Amplang is a kind of fish-based cracker. This snack product is a typical commodity of East Kalimantan. Every Regency/City in East Kalimantan tries to create amplang cracker that is unique to the Regency/City. For example, Samarinda City is famous for its flat fish amplang/mackerel, East Kutai Regency is famous for its "coal" amplang, and Kutai Kartanegara Regency for its milkfish amplang.

The amplang cracker industry in East Kalimantan can be said to be growing rapidly, as seen by so many entrepreneurs who choose to enter this business. Nevertheless, it indicates the intense competition among amplang crackers producers because they fight over the same market segment. Not to mention that the product quality, price, packaging and promotion system used are almost the same. Therefore, entrepreneurs are required to continue to innovate in order to create competitive advantages that make them different and superior to competitors.

In this study, researchers focus on developing business strategy for a SME called "Wanita Pesisir" that produces milkfish amplang cracker. This business is located in Saliki Village, Muara Badak District, East Kalimantan Province. This business consists of 10 women and produces an average of $50 \mathrm{~kg}$ of milkfish amplang crackers per week. Currently, the product distribution is still limited in the Muara Badak sub-district and several surrounding sub-districts (Wanita Pesisir, 2019). 
On the other hand, the development of technology and the internet have made business competition even tighter and more intense. Consumers increasingly have bargaining power with the producers/sellers. They increasingly have access to information regarding price, quality and specifications of a product. Consumer preferences are also dynamically changing, so that requires business players to be able to respond to these quickly and precisely so that their business is able to meet consumers' needs and wants and survive in a dynamic business world. Apart from providing challenges, technological developments and the internet actually offer opportunities to penetrate new, wider markets across countries and continents. This condition is certainly a challenge as well as an opportunity for SMEs, including "Wanita Pesisir" to develop their business.

According to data from the Central Bureau of Statistics in Sandi (2020), Indonesia currently has around 64 million MSMEs, but only $13 \%$ have switched or connected to digital. The rest, around $87 \%$ of MSMEs still rely on offline services ranging from buying and selling activities, bookkeeping, taxation, and so on.

In addition, the millennial generation with all its unique characteristics has become the consumer group with the largest population today. Based on Fool.com quoted by Buxton (2019), in 2018 the millennial generation began to surpass the purchasing power of the baby boomers generation; making this generation is potential consumers, whose preferences and purchasing behavior need to be identified. They have different desires from the previous generation. They like something unique, fresh, and instagramable, including in choosing food products.

Reflecting on this situation, "Wanita Pesisir" group needs to establish a business development strategy in order to grow rapidly both in terms of production and marketing and win the competition in the industry of amplang crackers. According to Wilkinson and Kannan (2013), strategic management is way of thinking, mental frameworks and approaches on an ongoing basis to monitor, analyze and evaluate the changes in the internal environment and the external company. Basically, strategic management represents the organization's efforts to create and maintain a competitive advantage.

One of strategic tools that is often used to scan an organization's internal and external environment is SWOT which stands for strength (strength), weakness (weakness), opportunity (opportunities) and threats (threats). According to Osita, et al. (2014), SWOT analysis is a very effective way to identify strengths and weaknesses and assess the opportunities and threats that may be faced so that organizations can focus on maximizing existing strengths and opportunities.

\section{LITERATURE REVIEW}

The business environment continues to change dynamically. A business that wants to sustainably survive the tough business competition must always update its business strategy. According to Rangkuti (2013), business strategy is functional strategy that is oriented to the functions of management activities, for example marketing strategy, production or operational strategy, distribution strategy, organizational strategy and strategies related to the finances of a business. Goldman and Nieuwenhuizen (2006) concluded that business strategy describes how a business will compete with new entrants, buyers, suppliers, and potential substitute products. By building a competitive strategy business owners can gain an understanding and insight into the business environment in which their business operates.

SWOT analysis is a systematic identification of various factors to formulate a company strategy. This analysis is based on logic that can maximize strengths (Strengths) and opportunities (Opportunities), but simultaneously can minimize weaknesses (Weaknesses) and threats (Thearts). The strategic decision-making process is always related to the development of the company's mission, objectives, strategies and policies. Thus strategic planning (strategic planner) must analyze the company's strategic factors (strengths, weaknesses, opportunities, and threats) in the current conditions. 
According to Agustinus (2010:85) SWOT can be defined as follows:

1. Strengths / Strength. This is an advantage of resources, skills and other capabilities relative to competitors and the needs of the market served. By testing the strengths that exist in the company, managers can find potential or identify what is different from other companies;

2. Weaknesses / Weaknesses. Is a limitation or deficiency in resources, skills and abilities that seriously hinder the effective performance of a company, by testing existing weaknesses, managers can identify weak points and assumptions that are not about the company's strategy;

3. Opportunities / Opportunities. This is a particularly advantageous situation in a corporate environment. By using information gathered from industry and competitive analysis, managers seek to identify opportunities for verification in new markets, new products or new technologies;

4. Threats / Threats. This is the main unfavorable situation in the company. By identifying the threats facing the company, strategies can be carried out to provide adequate defense against these threats.

Strengths and weaknesses are found in the body of a company, including certain business units, while opportunities and threats are environmental factors faced by the company concerned. If it is said that a SWOT analysis can be a powerful instrument in carrying out a strategy analysis, this capability lies in the ability of the company's strategy makers to maximize the role of the strength factor and the utilization of opportunities so that it also acts as a tool to minimize weaknesses in the body of the organization and suppress the impact of threats.

According to Putra (2016), millennials are those who were born between the 1980s and 2000s. Kotler and Amstrong (2013) in Moreno et al (2017) emphasizes that the millennial generation is the generation born between 1977 and 2000. They are the children of the baby boomers (born between 1946-1976) and even today are a larger segment than baby boomers. As the consumer group with the largest population today, millennials are promising target market for retailers. Therefore, it is important for business players to study millennial consumer behavior. According to Smith (2011) in Moreno et al (2017), millennials play an important role in the development of e-commerce. Growing up with socializing and shopping online, the use of e-commerce will continue to grow as their income increases. Although this generation dislikes pop-up ads, graphics are very effective at getting their attention, and they tend to repeatedly visit websites that offer competitive prices and good website design. Still in Moreno et al (2017), Ayaydin and Baltaci (2013) say that millennials spend more money on shopping, but have lower brand loyalty compared to previous generations. One of the reasons could be due to greater exposure to price promotions. Millennials are also looking for products and brands that match their personalities and can communicate their values. However, what retailers need to pay attention to is that the millennial generation is very sensitive to electronic word of mouth promotion or what is known as e-WOM (electronic word-of-mouth ) because according to them e-WOM is more credible than traditional advertising. They consider e-WOM to be a form of evaluation of people or consumers like them (Alls op, Basset and Hoskins, 2007). Moreno et al (2017) added that the millennial generation tends to spend their income faster than previous generations because their life philosophy is "living the moment and balancing work life with personal life", therefore they tend to take regular holidays and like collective learning, while providing their opinion to influence their peers.

Millennials love snacking. They see snacking as a necessity and snack food to be the dominant diet for many people in this generation. They are more likely to snacking 4 times or more in a day. The Asia Pacific region in particular, with a relatively younger population and growing middle income group, making it as the fastest growing snack market in the world (Asia Food Journal, 2017). Millennials want food that is easy to get, easy to make, delicious, and nutritious. At the same time, millennials are a group that travels a lot compared to previous generations. Many millennial consumers seek exotic foreign experiences. A survey by Forbes (2016) in Asia Food Journal (2017) revealed that millennial travelers want to fully 
immerse themselves in new cultures, and enjoy local dishes. This trend is also driving a strong influence on the food industry as producers strive to offer creative products with international flavors.

\section{METHODS OF RESEARCH}

This study uses a sequential mixed research approach to obtain comprehensive information from both consumers and business actors. Firstly, research done by gathering data from consumers regarding their snack preferences and buying behaviour. Since it is focused on millennials, so the population of the study must follow criteria below:

1. Millennial consumers (born between 1980 and 2000, or min. 20 - 38 years old);

2. Have ever consumed amplang crackers before.

Since number of population is unlimited/unknown, the sample determination uses a theoretical approach developed by Cochran (1977) with the following formula:

$$
p_{0}=\frac{z^{2} p q}{e^{2}}
$$

Where: $\mathrm{n}=$ the sample size we are looking for; $\mathrm{z}=\mathrm{z}$ table value (normal distribution table) at a certain level of confidence; $p=$ categorical proportion of the total of all categories; the value is a decimal value between $0-1$, for example $0.5,0.2$, etc; $q=$ proportion of categories other than $\mathrm{p}$ which is also written as $(1-\mathrm{p}) ; \mathrm{e}=$ margin error.

With margin error of $10 \%, n=(1.64)^{2}(0.5) \times(0.5) /(0.1)^{2}=67.24$ rounded off to 68 respondents. Due to pandemic, data gathered through online survey.

After data from consumers have been collected, then the research is continued with a qualitative approach through focus group discussions (FGD) with members of "Wanita Pesisir" to identify the internal strenghts and weaknesses as well as well as external opportunities and threats. Data obtained from consumer questionnaire responses and the FGD process will be analyzed using SWOT analysis and to understand its current business position and business development strategies.

\section{RESULTS AND DISCUSSION}

This research aims to study millennial consumers' snacking buying behaviour and preferences and then the result used to add broader understanding in designing business development strategy for SME that produces milkfish/amplang cracker called "Wanita Pesisir" by using SWOT analysis as framework.

In table 1 below displayed profiles of respondents who are Millennial consumers that have ever consumed amplang crackers before.

Table 1 - Respondents' Profiles

\begin{tabular}{llll}
\hline No. & Characteristics & Number & Percentage \\
\hline 1 & Gender & 20 & \\
& Male & $29.4 \%$ \\
2 & Female & 48 & $70.6 \%$ \\
& Age & 12 & $17.6 \%$ \\
& $17-22$ & 26 & $38.2 \%$ \\
& $23-28$ & 19 & $27.9 \%$ \\
& $29-34$ & 11 & $16.2 \%$ \\
3 & $35-39$ & & \\
& Marital Status & 32 & $47.1 \%$ \\
& Single & 33 & $48.5 \%$ \\
& Married & 3 & $4.4 \%$ \\
& Widow & & $19.1 \%$ \\
& Occupation & 13 & $25.0 \%$ \\
& Selif-Employed & 17 & $20.6 \%$ \\
& Private-Company Employee & 14 & $35.3 \%$ \\
\hline
\end{tabular}


Table 2 - Snack Buying Behaviour \& Preferences

\begin{tabular}{|c|c|c|c|}
\hline No. & Characteristics & Number & Percentage \\
\hline \multirow[t]{5}{*}{1} & Frequency of snacking & & \\
\hline & Every day & 9 & $13.2 \%$ \\
\hline & 3-6 times in a week & 22 & $32.4 \%$ \\
\hline & 1-2 times in a week & 26 & $38.2 \%$ \\
\hline & rarely & 11 & $16.2 \%$ \\
\hline \multirow[t]{6}{*}{2} & Reasons for snacking & & \\
\hline & Watching movie & 15 & $22.1 \%$ \\
\hline & Traveling & 6 & $8.8 \%$ \\
\hline & Studying/working & 15 & $22.1 \%$ \\
\hline & Souvenirs & 1 & $1.5 \%$ \\
\hline & Gathering with friends & 28 & $41.2 \%$ \\
\hline \multirow[t]{6}{*}{3} & Preferred place to buy & & \\
\hline & Convenience store & 37 & $54.4 \%$ \\
\hline & Small shop (warung) & 19 & $27.9 \%$ \\
\hline & Traditional market & 0 & $0 \%$ \\
\hline & Modern market & 8 & $11.8 \%$ \\
\hline & Online & 4 & $5.9 \%$ \\
\hline \multirow[t]{7}{*}{4} & Preferred/Wished Amplang Flavors & & \\
\hline & Original & 36 & $52.9 \%$ \\
\hline & Balado & 8 & $11.8 \%$ \\
\hline & Cheese & 4 & $5.9 \%$ \\
\hline & Corn & 2 & $2.9 \%$ \\
\hline & Hot \& Spicy & 17 & $25 \%$ \\
\hline & Others & 1 & $1.5 \%$ \\
\hline \multirow[t]{6}{*}{5} & Prefered Package size & & \\
\hline & $100 \mathrm{gr}$ & 12 & $17.6 \%$ \\
\hline & $250 \mathrm{gr}$ & 34 & $50 \%$ \\
\hline & $500 \mathrm{gr}$ & 15 & $22.1 \%$ \\
\hline & $1 \mathrm{~kg}$ & 6 & $8.8 \&$ \\
\hline & others & 1 & $1.5 \%$ \\
\hline \multirow[t]{7}{*}{6} & Preferred Packaging style & & \\
\hline & Zipped & 22 & $32.4 \&$ \\
\hline & Plastic & 7 & $10.3 \%$ \\
\hline & Stand up pouch & 12 & $17.6 \%$ \\
\hline & Composite can & 3 & $4.4 \%$ \\
\hline & Jar & 6 & $8.8 \%$ \\
\hline & Full/combined foil & 12 & $17.6 \%$ \\
\hline \multirow[t]{5}{*}{7} & Preferred Amplang Shape & & \\
\hline & Ball & 17 & $25 \%$ \\
\hline & Oval & 11 & $16.2 \%$ \\
\hline & Tiger nail & 39 & $57.4 \%$ \\
\hline & others & 1 & $1.5 \%$ \\
\hline
\end{tabular}

Source: Primary data, 2020.

As shown in table 2 above, we can conclude that the majority of respondents eat snacks 1-2 times a week, followed by 3-6 times a week. This result doesn't support Asia Food Journal (2017) who states that Millennials are more likely to snacking 4 times or more in a day. This makes sense because according to Hyslop (2020), recently Millennials and Gen Zs are more health conscious, demanding snacks that are healthy and nutritious. Added on that $92 \%$ of Indonesian snackers rank vitamin-rich, low sugar and fresh as the top three preferences in their choice of snacks. Besides that, mostly they consume snacks when they are with friends and prefer to buy snacks in convenience store the most.

In term of amplang buying preferences, surprisingly millennials still prefer the original flavor of amplang cracker. The other flavors that can be taken into consideration by business palyer to satisfy millennials such as hot \& spicy, balado, cheese, and corn respectively. In term of packaging, millennials prefer to have amplang cracker in zipped / wrapped package the most as it is more convenient and flexible to open and keep the remainig snacks.

Market research by asking consumers regarding their snack buying behaviour and amplang cracker preferences become one of the inputs in identifying opportunities for business strategy development. From focus group discussion with members of "Wanita Pesisir", here are the strengths, weaknesses, opportunities and threats identified as shown in Table 3.

Based on the calculation and placement of "Wanita Pesisir" business position with SWOT analysis, it is known that this business is located at the coordinate point $(1.25,1.86)$ 
as depicted in Figure 1, or in Quadrant I, which means many opportunities are identified so the recommended development strategy is an aggressive strategy, by taking advantage of opportunities and maximizing the internal strengths of the organization by increasing sales, increasing production capacity and market / product expansion.

Table 3 - SWOT Analysis of Wanita Pesisir Amplang Producer

\begin{tabular}{|c|c|c|c|c|c|c|c|c|}
\hline No & Strengths & Weight & Scale & $\begin{array}{l}\text { W } x \\
S\end{array}$ & Weaknesses & Weight & Scale & $\begin{array}{l}\text { W } x \\
S\end{array}$ \\
\hline 1 & High quality of raw material & 0.083 & 4 & 0,33 & $\begin{array}{l}\text { Traditional } \begin{array}{c}\text { production } \\
\text { equipments } \\
\text { numbers }\end{array} \text { with limited } \\
\end{array}$ & 0.056 & 2 & 0,11 \\
\hline 2 & Raw material is easy to get & 0.056 & 4 & 0,22 & $\begin{array}{l}\text { Traditional Packaging } \\
\text { process }\end{array}$ & 0.056 & 2 & 0,11 \\
\hline 3 & High product quality & 0.083 & 4 & 0,33 & $\begin{array}{l}\text { Unattractive package } \\
\text { design }\end{array}$ & 0.083 & 2 & 0,17 \\
\hline 4 & Skilled people & 0.083 & 4 & 0,33 & Limited flavor variations & 0.056 & 2 & 0,11 \\
\hline 5 & Loyal consumers & 0.083 & 4 & 0,25 & $\begin{array}{l}\text { Limited product distribution } \\
\text { coverage }\end{array}$ & 0.083 & 2 & 0,17 \\
\hline 6 & Good relationship between members & 0.083 & 3 & 0,22 & $\begin{array}{l}\text { Highly-depend on offline } \\
\text { marketing }\end{array}$ & 0.056 & 1 & 0,06 \\
\hline 7 & Obtain legal permits & 0.056 & 3 & 0,17 & $\begin{array}{l}\text { Limited capital inhibits } \\
\text { growth }\end{array}$ & 0.056 & 2 & 0,11 \\
\hline 8 & $\begin{array}{l}\text { Supervised by Department of } \\
\text { Fisheries \& Maritime Affairs }\end{array}$ & 0.056 & 3 & 0,22 & & & & \\
\hline & Total & & & 2.08 & & 1.00 & & 0.83 \\
\hline No & Opportunities & Weight & Scale & $\begin{array}{l}\text { W } x \\
S\end{array}$ & Threats & Weight & Scale & $\begin{array}{l}\mathrm{W} x \\
\mathrm{~S}\end{array}$ \\
\hline 1 & $\begin{array}{l}\text { Growing purchasing power of } \\
\text { Millennials }\end{array}$ & 0,107 & 4 & 0,43 & $\begin{array}{l}\text { Economy slowdown as the } \\
\text { impact of economy } \\
\text { recession }\end{array}$ & 0,107 & 2 & 0,21 \\
\hline 2 & Trend of modern snacks as souvenir & 0,107 & 5 & 0,54 & $\begin{array}{l}\text { Uncertainty of COVID-19 } \\
\text { pandemic }\end{array}$ & 0,107 & 1 & 0,11 \\
\hline 3 & $\begin{array}{l}\text { Trend of health consciousness } \\
\text { among people }\end{array}$ & 0,071 & 4 & 0,29 & $\begin{array}{l}\text { Rivalry among business } \\
\text { players in the industry }\end{array}$ & 0,107 & 2 & 0,21 \\
\hline 4 & e-Commerce development & 0,107 & 4 & 0,43 & $\begin{array}{l}\text { Threat from substitute } \\
\text { products }\end{array}$ & 0,071 & 2 & 0,14 \\
\hline 5 & $\begin{array}{l}\text { Government provides financial } \\
\text { stimulus \& support during the } \\
\text { COVID-19 Pandemic }\end{array}$ & 0,107 & 4 & 0,43 & & & & \\
\hline \multirow[t]{2}{*}{6} & $\begin{array}{l}\text { Opportunity to collaborate with } \\
\text { modern retail stores }\end{array}$ & 0,107 & 4 & 0,43 & & & & \\
\hline & Total & & & 2.54 & & 1.00 & & 0.68 \\
\hline
\end{tabular}

Source: Primary Data, 2020.

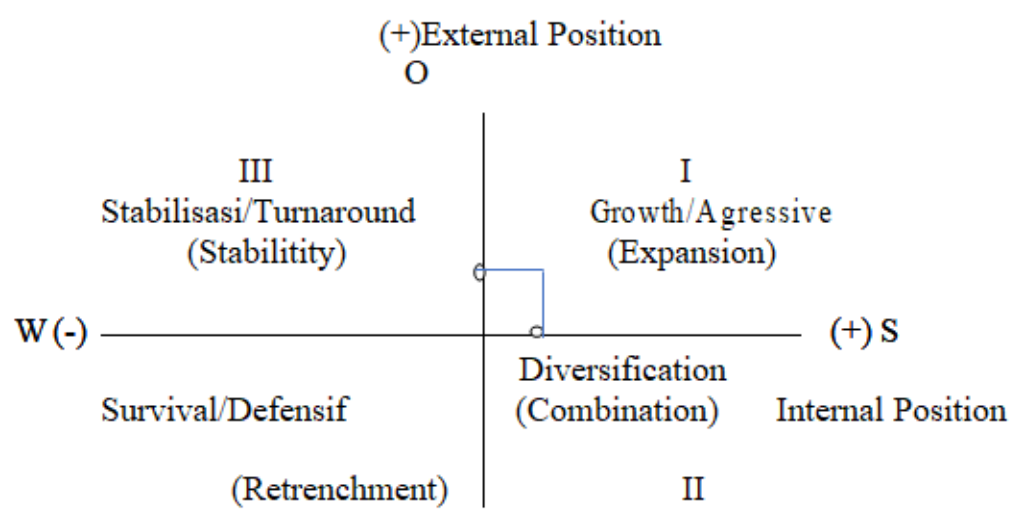

Figure 1 - Placement of Business Position of Wanita Peissir

Based on the SWOT analysis, aggressive strategies for Wanita Pesisir, Saliki Village, Muara Badak District include:

1. "Wanita Pesisir" can take advantage of social media such as Whatsapp, Facebook and Intagram and their advertising services to further promote their amplang products to a wider market segment; 
2. Having loyal customers is an advantage for every business. Use them as free promotional agents by creating a reference program or asking them to write / give testimonials about our products. Post customer testimonials on social media accounts to convince potential customers. Testimonials are one of the promotional styles that are currently widely used by entrepreneurs. According to Wang and Emurian (2005), this mechanism can serve as a substitute for interaction and help customers increase the level of trust;

3. Increase production capacity by recruiting new employees and / or purchasing production equipment that is more modern and has a larger capacity;

4. For financing, Wanita Pesisir can apply for a micro bank loan or other capital assistance provided by Banks. Besides that, during the COVID-19 pandemic government offers many financial supports/stimulus for SMEs;

5. Build cooperation and MoUs with raw material suppliers to maintain the stability of raw material prices and availability of raw materials;

6. Given the aggressive strategy, one of which is market expansion, "Wanita Pesisir" can market their products in electronic market places to reach a wider range of customers, not limited to East Kalimantan alone;

7. Collaborate with modern retail stores such as minimarkets / supermarkets to reach modern consumers;

8. Create differentiation, for example by adding a variety of unique flavors for example as suggested by this study like hot and spicy, balado, cheese, corn and so on. They can design attractive product package and package products in various sizes according to customer preferences.

\section{CONCLUSION}

SMEs play important roles in the economy as job creation agents, GDP contributor, and maintaining economy stability, so that it is important for government to continuously creating financial stimulus/support and updated training programs for them in order to grow bigger and stronger. According to this study, "Wanita Pesisir" business is in a good position and so should implement aggressive/growth business strategy.

Since the main actors in "Wanita Pesisir" are household mothers who may not understand the use of technology and social media, so the participation of younger generation who are creative and familiar with social media is needed to help support this business development efforts. By maximizing the use of social media and advertising services in it to promote products, they will be able to grab wider customers.

For future research, it is recommended to examine the effectiveness of paid advertising on social media as a medium for promoting SME products or other topics related to SME business development.

\section{REFERENCES}

1. Agustinus. (2010). Konsep-Konsep Dasar Analisis SWOT. 3rd ed. PT. Gramedia: Jakarta.

2. Allsop, D.T., Bassett, B. R., \& Hoskins, J. A. (2007), Word-of-Mouth Research: Principles and Applications, Journal of Advertising Research, 47 (4), pp. 398-411.

3. Asia Food Journal (2017), Millennials and Their Snacking Preference, [Online], (https://www.asiafoodjournal.com/2017/07/millennials-snacking-preference/2/, Accessed on 15 August 2019).

4. Buxton (2018), Ten Facts About Millennials that Every Retailer Should Know, [Online], (https://www.buxtonco.com/blog/10-facts-about-millennials-that-every-retailer-shouldknow, Accessed on 15 August 2019).

5. Cakti, A. (2020). Upaya Habis-Habisan Pemerintah dalam Memulihkan Sektor UMKM.

6. [Online]. Antara News. (https://www.antaranews.com/berita/1776857/upaya-habishabisan-pemerintah-dalam-memulihkan-sektor-umkm, Accessed on 28 December 2020) 
7. Goldman, G., Nieuwenhuizen, C. (2006), Strategy: Sustaining Competitive Advantage in a Globalised Context, [e-book], Cape Town: JUTA and Company Ltd.

8. Hyslop, G. (2020). Asian Millennials Have Evolved and so Has Snacking. [Online]. Bakeryandsnack.com.(https://www.bakeryandsnacks.com/Article/2020/03/09/Asianmillennials-have-evolved-and-so-has-snacking, Accessed on 28 December 2020).

9. Kurniawan, M., Haryati, N., (2017). Analysis of Business Development Strategy of Soursop Juice Beverage. Industria: Jurnal Teknologi dan Manajemen Agroindustri. 6 (2). pp. 97-102.

10. Moreno, F., M., et al (2017), The Characterization of the Millennials and Their Buying Behaviour, International Journal of Marketing Studies, 9 (5), pp. 136-144.

11. Osita, I.C., Idoko, O.R., Justina, N. (2014), Organization's Stability and Productivity: The Role of SWOT Analysis an Acronym for Strength, Weakness, Opportunity, and Threat, International Journal of Innovative and Applied Research, 2 (9), pp. 23-32.

12. Putra, Y.S. (2016), Theoretical review: Teori Perbedaan Generasi, Among Makarti, 9 (18), pp. 123-134.

13. Rangkuti, F. (2013). Analisis SWOT: Teknik Membedah Kasus Bisnis, Reorentasi Konsep, Perencanaan, Strategis Untuk Menhadapi Abad 21. PT.Gramedia: Jakarta.

14. Sandi, F. B. (2020). Peran UMKM di Indonesia yang Perlu Anda Ketahui. [Online]. Online Pajak. (https://www.online-pajak.com/seputar-pph-final/peran-umkm, Accessed on 28 December 2020).

15. Wang, Y. D., Emurian, H. H. (2005). An Overview of Online Trust: Concepts, Elements, and Implications. Computers in Human Behaviour. 21 (1). pp. 105-125.

16. Wilkinson, T. J., Kannan, V. R., (2013), Strategic Management in the 21st Century: The Operational Management, Vol. 1, [e-book], California: Praeger Publishers Accessed on 15 August 2019). 